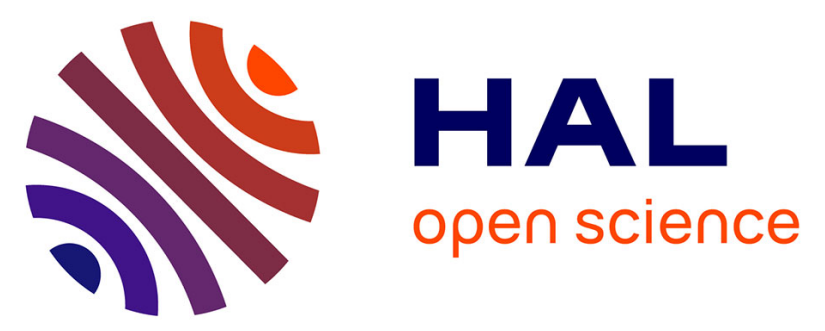

\title{
Local flexibility in feeding behaviour and contrasting microhabitat use of an omnivore across latitudes
}

Jean-Charles Leclerc, Thibaut de Bettignies, Florian de Bettignies, Hartvig

Christie, João N Franco, Cédric Leroux, Dominique Davoult, Morten F

Pedersen, Karen Filbee-Dexter, Thomas Wernberg

\section{To cite this version:}

Jean-Charles Leclerc, Thibaut de Bettignies, Florian de Bettignies, Hartvig Christie, João N Franco, et al.. Local flexibility in feeding behaviour and contrasting microhabitat use of an omnivore across latitudes. Oecologia, 2021, 10.1007/s00442-021-04936-5 . hal-03231854

\section{HAL Id: hal-03231854 \\ https://hal.sorbonne-universite.fr/hal-03231854}

Submitted on 21 May 2021

HAL is a multi-disciplinary open access archive for the deposit and dissemination of scientific research documents, whether they are published or not. The documents may come from teaching and research institutions in France or abroad, or from public or private research centers.
L'archive ouverte pluridisciplinaire HAL, est destinée au dépôt et à la diffusion de documents scientifiques de niveau recherche, publiés ou non, émanant des établissements d'enseignement et de recherche français ou étrangers, des laboratoires publics ou privés. 
4 Jean-Charles Leclerc ${ }^{1,2^{*}}$, Thibaut de Bettignies $^{3,4}$, Florian de Bettignies ${ }^{1}$, Hartvig

5 Christie $^{5}$, João N Franco ${ }^{6,7}$, Cédric Leroux ${ }^{8}$, Dominique Davoult ${ }^{1}$, Morten F.

6 Pedersen $^{9}$, Karen Filbee-Dexter ${ }^{4,10}$, Thomas Wernberg ${ }^{4,9,10}$

${ }^{1}$ Sorbonne Université, CNRS, UMR 7144 AD2M, Station Biologique de Roscoff, Place Georges Teissier, 29680 Roscoff, France

${ }^{2}$ Universidad Católica de la Santísima Concepción, Departamento de Ecología, Facultad de Ciencias, Centro de Investigación en Biodiversidad y Ambientes Sustentables (CIBAS), Casilla 297, Concepción, Chile

${ }^{3}$ UMS Patrimoine Naturel (PATRINAT), AFB-CNRS-MNHN, CP41, 36 rue Geoffroy Saint-Hilaire, 75005 Paris, France

${ }^{4}$ School of Biological Sciences \& UWA Oceans Institute, University of Western Australia, 39 Fairway, Crawley 6009, WA, Australia.

\begin{abstract}
${ }^{5}$ Marine Biology Section, Norwegian Institute for Water Research, Oslo, Norway
${ }^{6}$ CIIMAR, Terminal de Cruzeiros de Leixões. Av. General Norton de Matos, 4450-208 Matosinhos, Portugal

${ }^{7}$ MARE - Marine and Environmental Sciences Centre, ESTM, Instituto Politécnico de Leiria, Peniche, Portugal

${ }^{8}$ Sorbonne Université, CNRS, FR 2424, Station Biologique, Place Georges Teissier, 29680 Roscoff, France

${ }^{9}$ Department for Science and Environment (DSE), Roskilde University, PO Box 260, 4000 Roskilde, Denmark

${ }^{10}$ Benthic Communities Research Group, Institute of Marine Research, His, Norway
\end{abstract}

\title{
"leclercjc@gmail.com
}

Authors' contributions: JCL, TW and TdB conceived the ideas and designed the study. TW and

TdB obtained the initial funding. JCL, TdB, TW, HC, JF and KFD collected and processed samples

during field campaigns. CL processed isotope samples and JCL and FdB analysed the sea urchin drafts and discussion. 


\section{ABSTRACT}

32 As the environment is getting warmer and species are redistributed, consumers can be forced to

33 adjust their interactions with available prey, and this could have cascading effects within food

34 webs. To better understand the capacity for foraging flexibility, our study aimed to determine the

35 diet variability of an ectotherm omnivore inhabiting kelp forests, the sea urchin Echinus esculentus,

36 along its entire latitudinal distribution in the northeast Atlantic. Using a combination of gut content

37 and stable isotope analyses, we determined the diet and trophic position of sea urchins at sites in

38 Portugal $\left(42^{\circ} \mathrm{N}\right)$, France $\left(49^{\circ} \mathrm{N}\right)$, southern Norway $\left(63^{\circ} \mathrm{N}\right)$, and northern Norway $\left(70^{\circ} \mathrm{N}\right)$, and

39 related these results to the local abundance and distribution of putative food items. With mean

40 estimated trophic levels ranging from 2.4 to 4.6, omnivory and diet varied substantially within and

41 between sites but not across latitudes. Diet composition generally reflected prey availability within

42 epiphyte or understorey assemblages, with local affinities demonstrating that the sea urchin adjusts

43 its foraging to match the small-scale distribution of food items. A net "preference" for epiphytic

44 food sources was found in northern Norway, where understorey food was limited compared to

45 other regions. We conclude that diet change may occur in response to food source redistribution at

46 multiple spatial scales (microhabitats, sites, regions). Across these scales, the way that key

47 consumers alter their foraging in response to food availability can have important implication for

48 food web dynamics and ecosystem functions along current and future environmental gradients.

50 Key-words. Food web, Opportunism, Trophic plasticity, Urchin grazing, Laminaria hyperborea,

51 Echinus esculentus 


\section{INTRODUCTION}

Consumptive interactions (i.e., predation) can have major implications for the structure and

55 dynamics of communities (Chase et al. 2009; Vergés et al. 2019) and there are urgent needs for

56 determining their variations under changing climate and biodiversity redistribution (Sentis et al.

57 2014; Bruno et al. 2015; Rosenblatt and Schmitz 2016). In response to changes in prey abundances,

58 consumers can switch to alternative food items and/or readjust the strength of their interactions

59 with the prey (Sentis et al. 2014; Gilljam et al. 2015). In addition, and especially in the case of

60 ectotherms, some consumptive interactions can be strengthened due to changes in metabolic

61 requirements imposed by changing climate (Bruno et al. 2015; Rosenblatt and Schmitz 2016;

62 Anderson et al. 2017). The magnitude of these changes may, however, vary asymmetrically

63 between predators and prey depending on the differential thermal responses of both resource and

64 consumer traits, such as mobility and strategy to acquire resources (Dell et al. 2014). The diversity

65 of these scenarios is challenging predictions of future food webs and ecosystem functioning (Bruno

66 et al. 2015; Rosenblatt and Schmitz 2016; Kortsch et al. 2019; Vergés et al. 2019).

Latitudinal variation in species interactions has provided critical information on potential future changes with climate warming (Wernberg et al. 2010; Bennett et al. 2015a; Vergés et al. 2019). Large scale comparative experiments from various habitats have strongly improved our general understanding of both the structuring role of consumers on biodiversity gradients (Chase et al. 2009; Freestone et al. 2011; Bennett et al. 2015b; Roslin et al. 2017; Whalen et al. in press)

72 and of the global evolutionary patterns of plant defences and plant-herbivore interactions (Pennings

73 and Silliman 2005; Demko et al. 2017). To our knowledge, however, only a few studies have 74 investigated intra-specific patterns in the activity of consumers across broad climatic gradients. In 75 their latitudinal comparison of the feeding behaviour of the isopod Idotea balthica, Bell and Sotka 
76 (2012) revealed that this generalist grazer displayed local preferences for some of the food sources

77 available in different regions. In northeastern America, Anstett et al. (2014) compared the intensity

78 of grazing by different insects on the plant Oenothera biennnis and observed every possible

79 relationship (positive, non-significant or negative) with increasing latitude, likely due to plant-

80 herbivore specialization (versus generalism) and herbivore traits. Whether local adaptation or

81 phenotypic plasticity is to be invoked, these two examples support the idea that the trophic position

82 of resident consumers can vary across spatial scales. Notwithstanding its pervasiveness, our current

83 understanding of omnivory (i.e. wherein a consumer feeds on several trophic levels) within taxa

84 across such scales remains highly limited (Clay et al. 2017).

There is a growing interest in understanding how omnivory varies with environmental conditions, especially temperature, which has so far demonstrated mixed results (Rosenblatt and

87 Schmitz 2016; Anderson et al. 2017). The prevailing paradigm that the dietary proportion of carbohydrates increases more than proteins with increasing temperature (because carbon-rich

89 compounds are more readily processed to meet energy demands via respiration), has received 90 experimental support from a range of different ectotherms (marine copepods, caterpillars,

91 freshwater crayfish, tadpoles and insect larvae; Croll and Watts 2004; Lee et al. 2015; Boersma et

92 al. 2016; Carreira et al. 2016). Out of three tadpole species tested by Carreira et al. (2016), however,

93 the most carnivorous species were incapacitated when fed macrophytes in warming conditions.

94 This last result contrasts with the paradigm and suggests that omnivory responses to temperature

95 may instead depend on initial species-specific diets (nutrient limitations), as also supported by

96 stoichiometric models (Anderson et al. 2017) (cf. Sperfeld et al. 2017 for further confrontation of

97 related theorotical frameworks). Increased consumption of protein over carbohydrates with

98 increasing temperature, in order to promote growth, development and survival, has been 
99 experimentally shown in a grasshopper fed artificial diets (Schmitz et al. 2016) and more indirectly

100 (through varied C:N) in a beetle fed various plant species (Lemoine et al. 2013). Conversely, in

101 cold conditions, carbohydrate consumption may be enhanced to compensate for reduced energy

102 intake, as also suggested from experiments on the mealworm beetle fed synthetic diets (Rho and

103 Lee 2017). Based on such premises, it is of little surprise to find inconsistent seasonal variations in

104 omnivory across field studies (Miyasaka and Genkai-Kato 2009; Boersma et al. 2016), and calls

105 for additional comparative studies across multiple spatial scales and environments.

In this study, we examined the omnivory of a broadly distributed ectotherm consumer - the

107 sea urchin Echinus esculentus (hereafter Echinus) - across latitudes that are representative of 108 different climatic conditions. Echinus inhabits kelp forests along the latitudinal distribution of the

109 kelp Laminaria hyperborea, ranging from Portugal $\left(\sim 41^{\circ} \mathrm{N}\right)$ to northern Norway $\left(71^{\circ} \mathrm{N}\right)$ (Tyler et

110 al. 1995). A substantially varied diet has generally been reported for the species, but has to the best

111 of our knowledge, never been compared across larger spatial scales and environments, in spite of

112 interesting patterns suggested by local-scale studies (see methods). Importantly, animal proteins

113 (and possibly lipids) are seemingly required in Echinus' diet to promote its somatic growth and

114 reproductive output (Bonsdorff and Vahl 1982; Kelly et al. 2001). This is also observed in other

115 sea urchins (e.g., Lares and McClintock 1991; Fernandez and Boudouresque 2000). In marine

116 systems, the amounts (per unit of dry mass) of proteins and lipids in sessile fauna are on average

1173.2 and 5.5 times higher in than in seaweeds, which contain 3.9 times more carbohydrates than

118 fauna (Brey et al. 2010). Assuming the energy investment in foraging on the two food categories

119 is identical (both being sessile, Dell et al. 2014), we first hypothesized that (1) the sessile fauna

120 intake would be greater in warmer conditions, therefore producing an omnivory gradient across

121 latitudes. While absolute consumption rate could also vary with temperature (Bruno et al. 2015) 
122 and thus counterbalance temperature-driven metabolic nutrient limitation (Anderson et al. 2017),

123 we also had the alternative hypothesis that (2) the balance between animal and algal food would

124 vary according to the local availability of food items, hence indicating an entirely opportunistic

125 behaviour uncoupled, at least directly, from climatic conditions. Should omnivory be driven by

126 opportunism, we further hypothesized that (3) the consumer would locally adjust its foraging

127 strategy at multiple spatial scales.

\section{METHODS}

130 Model species

131 Although the vast array of putative prey of Echinus is generally acknowledged and supported by

132 qualitative observations of gut contents made in Western Scotland (Comely and Ansell 1988;

133 Emson and Moore 1998), the Isle of Man (Moore 1934) and the English Channel (Leclerc et al.

134 2015), information regarding broad spatial variations in diet is generally lacking. Differences in

135 gonad condition across shallow and deep sites reported in previous studies have often been

136 attributed to contrasting diversity and availability of food items (Moore 1934; Nichols et al. 1985).

137 In addition, local-scale studies using stable isotopes have indicated that Echinus has a substantially

138 varied diet largely dominated by kelp in Norway (Fredriksen 2003) and by sessile fauna in France

139 (Leclerc et al. 2015). Whether these differences in diet reflect local response to available food

140 sources, changes relating to metabolic requirements or is incidental (e.g., as a function of different

141 temperature regimes) is unresolved.

142 Study sites and sampling 
143 The sampling design consisted of four regions (separated by 1000s of kilometres), with two sites

144 (separated by $1-10 \mathrm{~s} \mathrm{~km}$ ) nested within each region. The study area ranged from northern Portugal

$145\left(41.6^{\circ} \mathrm{N}\right)$ to northern Norway $\left(69.6^{\circ} \mathrm{N}\right)$, hence covering $28^{\circ}$ of latitude (Table $\left.\mathrm{S} 1\right)$. Mean sea surface

146 temperatures (extracted from the Bio-Oracle database; Tyberghein et al. 2012; Assis et al. 2018 for

147 the period 2000-2014, Table S2) ranged from $7.0^{\circ} \mathrm{C}$ in northern Norway (average minimum and

148 maximum between 3.3 and $11.3^{\circ} \mathrm{C}$ ) to $15.6^{\circ} \mathrm{C}$ in Portugal (between 13.0 and $18.2^{\circ} \mathrm{C}$ ). Over the

149 same period, long-term temperature variations were weak in Portugal (range of $\sim 5^{\circ} \mathrm{C}$ ) and France

$150\left(6^{\circ} \mathrm{C}\right)$, under the direct influence of the Gulf Stream, moderate in northern Norway $\left(8^{\circ} \mathrm{C}\right)$ and

151 comparatively greater in southern Norway $\left(10^{\circ} \mathrm{C}\right)$. Each study site was haphazardly selected among

152 Laminaria hyperborea forests at a depth of 5-12 m below chart datum. Adult Echinus were

153 'frequent' (SACFOR scale) at all study sites (1-9 ind. $10 \mathrm{~m}^{-2}$ ). Within each study site, 16 to 20 sea

154 urchins, 6 young (stipe < ca. $5 \mathrm{~cm}$ ) and adult (stipe > ca. $5 \mathrm{~cm}$ ) kelps were haphazardly collected

155 by divers, kept on ice and then processed in the laboratory within 12 hours. Within the framework

156 of distinct field campaigns, sampling was done in spring 2014 in France and southern Norway, in

157 spring 2015 in Portugal and in summer 2016 in northern Norway.

The abundance of primary producers and all potential urchin food sources (including sessile

159 fauna) were assessed using two distinct methods. At the site scale, the fleshy seaweed biomass (wet

160 weight: blotted with paper tissue and weighed) was determined at the lowest taxonomic level

161 possible (generally species) from destructively sampled $0.25 \mathrm{~m}^{2}$ quadrats. In the laboratory,

162 seaweed biomass was further subdivided into two categories, either epilithic (on bedrock) or

163 epiphytic (on kelp stipe). In addition, a series of independent photos were taken to determine the

164 abundance of all potential food sources (including fauna) within the main strata of the kelp forest:

165 bedrock $(n=5-11)$ and stipe $(n=5-11)$. These potential food sources were classified using morpho- 
166 functional groups of seaweeds and sessile fauna, which have proven relevant to address ecological

167 functions of complex stratified systems such as Laminaria hyperborea forests (see Appendix S1).

168 Percentage covers of morpho-functional groups of seaweeds and sessile fauna were visually

169 estimated by the same observer (JCL) from photos for each potential food source. These

170 estimations followed the Dethier et al. (1993) framework, by summing semi-abundance either over

171 sub-quadrats of the quadrats $(0-4 \times 25)$ or over linear (vertical) portions of the stipe $(0-10 \times 10)$.

172 Most fleshy seaweeds and their epiphytes (notably sessile fauna) were generally visible in photos,

173 making easier their abundance estimation easier. In both habitats, however, most understorey taxa

174 (crusts and small sessile fauna) or habitat features (sediment) could not be quantified and were thus

175 likely underestimated. While percentage cover were assessed with a fixed scale of $0.1 \mathrm{~m}^{2}$ on the

176 bedrock, stipe area available to colonization by epiphytes varied across kelp individuals and was

177 not quantified. Nonetheless, differences in surface area (among stipes or between stipes and

178 quadrats) were not considered an issue in the context of our study since relative values of cover,

179 based on similar sampling intensity and broad functional groups (rather than species) were only

180 compared among these strata and gut contents (see section on data analyses).

182 Urchin diet and trophic position

183 In the laboratory, sea urchins were processed for a series of morphological parameters, such as

184 their size (maximum test width) and gonad index (ratio between gonad and total wet biomass).

185 Aristotle's lanterns and guts were dissected and stored in separate Ziploc bags at $-30^{\circ} \mathrm{C}$ until further

186 analysis. Unlike stable isotopes which give a time-integrative estimation of diet, gut contents give

187 a snapshot of feeding choices but are more robust to determine preferences and opportunism. Gut 
contents also provide accurate information about prey species which have been ingested and are

189 therefore useful in determining individual habitat use and foraging strategies, within and among 190 sites (Vanderklift et al. 2006).

Gut contents from individual sea urchins were analysed in order to determine any food

192 preferences. To facilitate identification, gut contents were washed thoroughly with freshwater

193 through an $80 \mu \mathrm{m}$ mesh sieve. Each gut sample was then placed within a Dollfus's dish $(50 \times 100$

$194 \times 8 \mathrm{~mm})$, where the bottom was divided into 200 square compartments $(5 \times 5 \times 2 \mathrm{~mm})$. Although

195 crushed by the sea urchin teeth over ingestion and reduced to $<2-5 \mathrm{~mm}$ pieces within faecal pellets,

196 most prey items are readily identifiable using a series of morphological and histological traits (e.g.

197 Emson and Moore 1998). For each food item category (morpho-functional group, Appendix S1), a

198 score was given according to its occurrence over the total number of occupied squares. Each food

199 item score was finally reported as a percentage, the sum of which frequently exceeded $100 \%$ given

200 the over-layering of food item categories within the bulk sample.

Stable isotope analyses were conducted on individual urchins and on the biomass-dominant primary food source in order to estimate urchin trophic level. Laminaria hyperborea was expected

203 to be the most abundant fleshy seaweed (except in Portugal, see results) and the only seaweed

204 shared across all study sites. Within kelp forests, L. hyperborea also represents the dominant 205 trophic resource of sessile suspension-feeders (e.g. barnacles, bivalves, bryozoans), which can be 206 a major component of Echinus diet (Leclerc et al. 2013; 2015). Given these reasons and in the 207 absence of suspension-feeders isotope values (see also Post 2002) collected for this study, $L$. 208 hyperborea was chosen as baseline, using average $\delta^{15} \mathrm{~N}$ values of adult and young kelp individuals, 209 generally in the range of other seaweeds (Leclerc et al. 2013). Clean sections of kelp (ca. $4 \times 4 \mathrm{~cm})$ 
210 were dissected from newly-formed lamina on freshly collected adult kelp and around the meristem

211 (stipe and lamina) on young kelp. For Echinus, muscle tissues, reflecting time-integrative

212 assimilation of sources (e.g. Pinnegar and Polunin 1999), were dissected from the Aristotle's

213 lantern. Each sample was checked and when necessary cleaned from epiphytes using a scalpel,

214 thoroughly rinsed with filtered seawater, then oven-dried at $55^{\circ} \mathrm{C}$ for $48 \mathrm{~h}$. Because $\delta^{15} \mathrm{~N}$ values

215 were targeted, no further treatment was deemed necessary. Dried samples were ground using an

216 agate mortar and a pestle, then put in tin capsules for mass-spectrometry analyses.

217 Nitrogen isotope-ratios were determined using a Flash EA-CN analyser coupled with a

218 Finnigan Delta Plus mass spectrometer, via a Finnigan Con-Flo III interface. Data are expressed in 219 the standard $\delta$ unit, calculated in relation to the certified reference material atmospheric dinitrogen

220 (at-air): $\delta^{15} \mathrm{~N}=\left[\left({ }^{15} \mathrm{~N} /{ }^{14} \mathrm{~N}_{\text {sample }} /{ }^{15} \mathrm{~N} /{ }^{14} \mathrm{~N}_{\text {reference }}\right)-1\right] \times 10^{3}$. The at-air scale was calibrated against

221 IAEA-N2 and USGS34 international standards, using a two-point normalisation (Paul et al. 2007).

222 In addition, a laboratory standard (casein IRMS certified standard, B2155 Elemental Microanalysis

223 Ltd, UK) is used throughout the analyses, as quality check. The standard deviation of repeated 224 measurements of $\delta^{15} \mathrm{~N}$ values of a laboratory standard was $0.05 \%$ versus at-air.

226 Data analyses

227 Estimation of trophic level using stable isotopes

228 Isotopic analyses helped to estimate trophic levels of each individual urchin ( $\left.\mathrm{TL}_{\mathrm{urchin}}\right)$ : $\mathrm{TL}_{\mathrm{urchin}}=1$

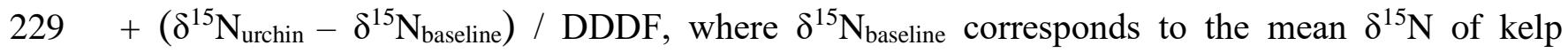
230 (averaged over adult and young kelps per site) and DDDF corresponds to diet-dependent 
231 discrimination factor $\left(\Delta^{15} \mathrm{~N}\right)$ calculated for each site according to Caut et al. (2009). This method

232 was chosen due to the omnivory of Echinus and given the large variability in kelp $\delta^{15} \mathrm{~N}$ observed

233 among sites (see also Figure S4). No discrimination factor has been proposed for sea urchins

234 (e.g.,Vanderklift et al. 2006) and the use of a fixed $\delta^{15} \mathrm{~N}$ led to contradictory results in comparison

235 with gut contents analyses (overestimation of TL at sites where kelp were poorly enriched in ${ }^{15} \mathrm{~N}$ ).

236 In addition, dependency between $\operatorname{diet} \delta^{15} \mathrm{~N}$ and discrimination factor has been experimentally

237 demonstrated in other echinoderms (Blanchet-Aurigny et al. 2012).

239 Statistical analyses

240 All univariate and multivariate data were analysed using the same two-way nested

241 PERMANOVAs, with 4999 permutations and the random factors 'region' and 'site'. Univariate

242 and multivariate analyses were respectively based on Euclidean distance and Bray-Curtis similarity

243 matrices. Univariate data included urchin size, gonad index and trophic level as well as the

244 abundances of the dominant groups of putative food items (biomass of kelp and other seaweeds,

245 percentage cover of seaweeds and sessile fauna), on either bedrock or stipe. Multivariate data

246 consisted of the relative abundances of each food item categories within gut contents. Prior to

247 analyses, the homogeneity in univariate or multivariate dispersion was checked among the levels

248 of the factor 'region' using PERMDISP (Anderson et al. 2008). When assumption of

249 homoscedasticity was not met after any transformation of univariate data, the analysis was

250 conducted on untransformed data following Underwood (1997) and a more conservative level of

251 significance $(\alpha=0.01)$ was taken into account. For multivariate structure, samples were also

252 ordinated using non-metric multidimensional scaling (nMDS) to support PERMANOVA results

253 (Anderson et al. 2008). In order to strengthen all these analyses, we also examined how the 
254 variation was distributed across all three nested levels tested (region site, residual). When a 255 negative component of variations was found, it was set to zero and the model was adjusted in order 256 to re-calculate the remaining estimates (Fletcher and Underwood 2002).

Foraging strategies were determined from gut content similarities with prey distribution in 258 the sea urchin environment. At the site scale, the natural habitat-complexity of $L$. hyperborea 259 forests challenges the collection of abundance data for all possible food sources (Christie et al. 260 2003; Leclerc et al. 2016). More information can, however, be obtained from the abundances of 261 resource on two kelp forest strata known to be visited by Echinus: the understorey (on the bedrock) 262 and the epiphytes (on the stipe). We thus developed a relative and binary feeding behaviour index 263 for each of these two strata. First, abundance (cover) data of the main food item categories (except 264 kelp) in different habitats (bedrock and stipe) and within urchin guts were all compiled in a unique 265 matrix. We did not include kelp in the analyses because they were often observed in the urchin diet 266 as a varying mixture of fragment types (ranging from a relative scale of soft to hard tissues, with 267 or without cortex, etc.), which could hardly be assigned to understorey or stipe. Indeed, these 268 diverse type of tissues can be found in varying abundances within either canopy kelp individuals 269 (Kain 1963), understorey young individuals, or detritus (Filbee-Dexter et al. 2018). Second, a 270 matrix of dissimilarity between all pairs of samples was created using the Bray-Curtis index 271 calculated from untransformed data. Third, for each site, principal coordinates were calculated 272 from the Bray-Curtis dissimilarity (non-metric) matrices in order to extract Euclidean distances 273 (metric) between all pairs of samples, while preserving the properties of the Bray-Curtis index. 274 Fourth, for each individual urchin, the average distance between its diet and the food item 275 abundances in each of its putatively targeted habitats (stipe or bedrock) was then calculated. Fifth, 276 the relative and binary feeding behaviour index (FBI) was subsequently calculated for each 
277 individual, based upon Armas et al. (2004), as follow: $F B I=\left(D_{d-h 1}-D_{d-h 2}\right) /\left(D_{d-h 1}+D_{d-h 2}\right)$, where

$278 \mathrm{D}_{\mathrm{d}-\mathrm{h} 1}=$ multivariate distance between individual diet and the habitat 1 (here bedrock) and $\mathrm{D}_{\mathrm{d}-\mathrm{h} 2}=$

279 distance between individual diet and the habitat 2 (stipe). This FBI presents a continuous scale and

280 ranges between -1 and +1 indicating a marked (and theoretical) affinity for habitats 1 and 2 ,

281 respectively. Finally, in order to determine whether urchins present a significant "preference" for

282 one habitat or another at the local scale, PI values were compared to 0 using one-sample $t$-tests

283 within each site. The latter analysis was performed using SigmaPlot, while PERMANOVAs, 284 nMDS and PERMDISPs were performed using PRIMER 7 with PERMANOVA add-on (Anderson 285 et al. 2008).

\section{RESULTS}

288 Across sites and regions, a total of 131 sea urchins were analysed and presented consistent regional

289 differences in both size (test diameter) and wet weight (ww) between core (France, southern

290 Norway) and edge (Portugal, northern Norway) regions (Table 1, Fig. S1). Sea urchins were

291 significantly smaller in Portugal $(85.3 \pm 7.4 \mathrm{~mm}$, mean \pm SD) and northern Norway (78.1 \pm 12.3

$292 \mathrm{~mm})$ than in France $(113.3 \pm 10.1 \mathrm{~mm})$ and southern Norway $(110.8 \pm 15.7 \mathrm{~mm})$. Likewise, and in

293 spite of within-region significant effects, sea urchins were three times lighter $\left(85.3 \pm 7.4 \mathrm{~g}_{\mathrm{ww}}\right)$ in

294 Portugal $\left(274.4 \pm 62.5 \mathrm{~g}_{\mathrm{ww}}\right)$ and northern Norway $\left(224.6 \pm 107.6 \mathrm{~g}_{\mathrm{ww}}\right)$ than in France $(778.3 \pm$

$\left.295222.8 \mathrm{~g}_{\mathrm{ww}}\right)$ and southern Norway $(673.5 \pm 217.3 \mathrm{~g})$. Their gonad index varied substantially within

296 sites (72\% of variation due to residuals in the model, Table 1) but did not vary among regions (on 
297 average $7.2 \pm 4.04$, Fig. S1). Interestingly though, this index displayed significant site-to-site

298 differences in both Portugal and northern Norway (Table 1, Fig. S1).

300 Food availability varied markedly across different spatial scales (among regions, sites, micro-

301 habitats), and depended on food type. Laminaria hyperborea dominated the seaweed biomass from

302 France $\left(5.6 \pm 4.5 \mathrm{~kg}_{\mathrm{ww}} \mathrm{m}^{-2}\right.$, mean $\left.\pm \mathrm{SD}\right)$ to northern Norway $\left(13.7 \pm 11.3 \mathrm{~kg}_{\mathrm{ww}} \mathrm{m}^{-2}\right.$, Fig. $1 \mathrm{~A}$, Table

303 1), where similar values were observed, but its biomass was much lower $\left(<0.1 \mathrm{~kg}_{\mathrm{ww}} \mathrm{m}^{-2}\right)$ in

304 Portugal, where the canopy was dominated by the pseudo-annual kelp Sacchoriza polyschides (0.9

$305 \pm 0.3 \mathrm{~kg}_{\mathrm{ww}} \mathrm{m}^{-2}$, Fig. 1B). The epiphyte biomass was statistically similar among regions (Fig. 1C,

306 Table 1), and highly variable within and among sites (cf. \%var. in Table 1). It is noteworthy that

307 epiphyte biomass was virtually zero at all sites in Portugal and at the Hekkingen site (cf. Table S1)

308 in northern Norway. Significant regional differences were detected for the understorey biomass

309 (Fig. 1D). In northern Norway, the fleshy algal understorey was patchy, monospecific

310 (Desmarestia aculeata and the biomass was negligible $\left(5.1 \pm 15.6 \mathrm{~g}_{\mathrm{ww}} \mathrm{m}^{-2}\right)$ when compared to

311 other regions (Table 1, Fig. 1D). Understorey biomass was similar in France $\left(80.4 \pm 78.1 \mathrm{~g}_{\mathrm{ww}} \mathrm{m}^{-2}\right)$

312 and southern Norway $\left(84.6 \pm 831 \mathrm{~g}_{\mathrm{ww}} \mathrm{m}^{-2}\right)$ and about ten-fold lower than in Portugal (775.9 \pm 665.5

$313 \mathrm{~g}_{\mathrm{ww}} \mathrm{m}^{-2}$, Table 1, Fig. 1D). Similar spatial patterns were shown when fleshy seaweeds were

314 quantified using percentage cover with only the epilithic algae differing significantly between

315 northern Norway (10.0 $\pm 7.1 \%$, dominated by crusts, Fig. 2) and the other regions (on average 55.9

$316 \pm 16.1 \%$, Table 1, Fig. 2). In contrast, neither the percent cover of sessile fauna associated with the

317 stipes or with the bedrock differed among regions, but both displayed substantial site-to-site

318 variations in France and northern Norway (Table 1, Fig. 2). 
320 Both stable isotope and gut content analyses were indicative of omnivory, without preference for

321 a specific food source (Fig. 3, Fig. S4). A total of 22 food items could be identified in the sea urchin

322 guts, including diverse morpho-functional groups of seaweeds (including kelp across all study

323 sites), sessile and mobile fauna (Fig. S3). Within faunal groups, barnacles (Cirripeda) and

324 bryozoans displayed the greatest contribution to the urchin diet (Fig. 3B). In spite of a great site

325 within region effect, the multivariate structure of the diet varied significantly among regions (cf.

326 PERMANOVA). However, pairwise tests only reveal statistical difference between Portugal,

327 southern Norway and northern Norway; all diets were similar to samples from France (Table 1,

328 Fig. 3C). The trophic level varied substantially between sites within region in Portugal, France and

329 northern Norway, and no difference was detected among regions (Table 1, Fig. 3A). For instance,

330 the trophic level in France

332 Adjustment of foraging strategy at multiple spatial scales

333 Analysing the similarity between the generalist diet and the distribution of its putative food items

334 proved efficient to infer spatial patterns in foraging strategies in space, here between two kelp forest

335 strata: the bedrock and the stipe (Fig. 4). Although broad groups of sessile taxa were considered,

336 the community (or functional) structure of these strata differed significantly within and across study

337 sites (Table S3, Fig. S2). Based on these cover data, sea urchins displayed significant net affinity

338 for one habitat or another in 6 out of the total 8 sites (Fig. 4). Within regions, consistent affinities

339 for the understorey habitats were observed in Portugal whereas consistent affinities for the epiphyte 
340 habitats were found in northern Norway. Site-specific affinities for the understorey were also

341 observed in France and southern Norway (cf. also site within region effect, Table 1), but it is

342 noteworthy that many individuals (15.5\%) from southern Norway displayed a net affinity for the

343 epiphytes (PI ranging from +0.05 to +0.18 , Fig. 4A)

\section{DISCUSSION}

346 Consumers are expected to adjust their diet and/or the strength of their interactions in response to

347 the redistribution of their food items and to metabolic changes imposed by global warming (Bruno 348 et al. 2015; Gilljam et al. 2015; Rosenblatt and Schmitz 2016; Anderson et al. 2017). Our results

349 show that neither diet nor trophic level of an omnivore sea urchin inhabiting kelp forests varied 350 significantly among regions across approximately $28^{\circ}$ latitude on the NE Atlantic, suggesting that

351 temperature or other covariates of latitude did not influence, at least directly, the feeding 352 preferences of this ectotherm. With respect to variations among sites, however, the diet of sea 353 urchins varied according to local availability of food items. By using a feeding behaviour index, 354 our results further indicate that sea urchins locally adjusted their foraging strategy among kelp 355 forest strata, consistent with great functional plasticity.

358 Metabolic scaling theory (Bruno et al. 2015), the foraging strategy towards sessile prey (Dell et al. 359 2014) and previous published diets of Echinus from local studies (Fredriksen 2003; Leclerc et al. 360 2015) suggest that animal (protein rich) food intake of this sea urchin should decrease with ocean 361 warming, and therefore with increasing latitude. Although we do not provide evidence on possible 
362 individual diet adjustments with temperature (within populations), the latitudinal hypothesis

363 (among populations) is generally rejected by this study. By analysing both gut contents and stable

364 isotopes, our results indicate that Echinus maintains omnivory (algal versus animal contribution to

365 the diet) across its latitudinal range. Should temperatures experienced by the sea urchin across its

366 latitudinal range have any influence on its metabolic requirements, our results would align best

367 with models in which stoichiometric imbalance, and dietary preferences, can be preserved by

368 overall increased intake with temperature (Anderson et al. 2017). While temperature is most likely

369 to affect per capita interaction strength, it does not seem to affect Echinus food preference at the

370 latitudinal scale studied. Diverse groups of algae and animals were consistently identified as part

371 of the urchin diet at all study sites (e.g. bryozoans, barnacles, kelp and fleshy seaweeds) and nothing

372 indicated a latitudinal shift in their respective abundance. Using stable isotopes $\left(\delta^{15} \mathrm{~N}\right)$, estimates

373 of trophic level generally aligned with the relative abundance of food items in digestive contents

374 and previous local studies. For instance, the highest trophic level (4.6 \pm 0.2$)$ observed in Roscoff

375 (France) is consistent with Leclerc et al. (2015) estimations in a nearby locality $(\mathrm{TL}=4.0)$, wherein

376 a similar diet was observed. The lowest trophic level $(2.4 \pm 0.2)$ estimated in Hekkingen (northern

377 Norway) was also consistent with a kelp-dominated diet shown by gut content analyses. While the

378 trophic level was consistent across regions, it varied markedly among sites within region, providing

379 support to alternative hypotheses, notably related with food availability (see following sections).

Omnivory reflects local food availability across multiple spatial scales

The overall site-to-site variability in both $\delta^{15} \mathrm{~N}$ and gut contents suggests that spatial patterns

383 in omnivory may be driven mainly by opportunism (in response to food availability) as opposed to 
384 latitudinal characteristics of the environment. While feeding trials would have provided empirical

385 evidence for this hypothesis (Bell and Sotka 2012; Demko et al. 2017), qualitative site-to-site 386 comparisons of the heat-maps illustrating the abundances of putative food sources within the 387 understorey (Fig. S2) and the contributions of each food item to the diet of Echinus (Fig. 2-3, Fig. 388 S3) shed some light on this pattern. For instance, filamentous algae were virtually absent from gut 389 contents in all sites, except in southern Norway where they dominated the understorey and 390 represented a major component of the urchin diet, regardless of likely limited benefits for macro391 consumers (Steneck and Watling 1982). As previously suggested in local studies (Emson and 392 Moore 1998), our results support that site-to-site differences in diets are mostly driven by food 393 availability. These differences could also be reflected in Echinus phenology (Moore 1934; Nichols 394 et al. 1985; Comely and Ansell 1988) but we note in that context that relationships between the 395 spawning cycle and diet are generally unresolved for Echinus, unlike other well-studied sea urchins 396 (Minor and Scheibling 1997; Fernandez and Boudouresque 2000). Spatial variations in gonad 397 index and food availability can either be consistent (e.g. between young individuals living in 398 faunal-dominated deep reefs and adults living in seaweed rich-shallow reefs, Moore 1934; Nichols 399 et al. 1985) or counter-intuitive (e.g. with considerable variations in the timing of spawning events 400 between apparently similar sites, Comely and Ansell 1988). Likewise, much site-to-site variations 401 in gonad index were observed in both Portugal and northern Norway. While this variation coincides 402 with site-to-site differences in sea urchin size in Portugal (see also Moore 1934), it rather coincides 403 with substantial site-to-site differences in diet and availability of attached fleshy seaweeds 404 (seasonally consistent, KFD, pers. obs.) in northern Norway. These complex relationships certainly 405 deserves attention beyond the scope of this study. 
407 indicated by our feeding behaviour index, which may help to inform of the underlying processes 408 and ecological implications of such flexibility at multiple spatial scales. The consistent occurrence 409 of certain food items in diets at all sites suggests that some of them could be important to the urchin 410 fitness (e.g. kelp, fleshy seaweeds colonized by crustose bryozoans, Bonsdorff and Vahl 1982). In

411 order to obtain these food items in heterogeneous habitats, the sea urchins may be forced to adjust 412 their foraging strategies at the local scale (cf. Paracentrotus lividus in seagrass meadows, Camps413 Castellà et al. 2020). Because the abundance and distribution of food items across kelp forest strata 414 can vary consistently across broad diversity gradients (e.g. some broadly distributed taxa are 415 exclusive to kelp stipes, Kain-Jones 1971), local adjustments in foraging strategies are likely to 416 create gradients in Echinus function at a larger scale.

At the southern (warm) edge of Laminaria hyperborea distribution (Portugal), kelp were 418 reduced to small individuals with little to no epiphytes, and there was virtually no stratification 419 (i.e., canopy/sub-canopy) of the kelp forests. In the same region, our index revealed a net affinity 420 for the understorey, where the seaweed biomass was concentrated (Fig. 3B, Fig. S3) and included 421 the few species observed on the stipe (e.g. Rhodymenia sp.). Range centre populations of Echinus 422 in France and southern Norway were in different kelp forest conditions compared to Portugal, and 423 had access to both epiphytes and understorey seaweeds. Laminaria hyperborea forests were similar 424 within and between these two regions, with the prevalence of large kelp individuals (main biomass) 425 loaded by abundant epiphytes (including kelp). The same sites in France and southern Norway 426 were also accompanied by diverse seaweeds and sessile animals growing on the surrounding 427 bedrock. In these kelp forests, our feeding behaviour index suggests that Echinus can encounter 428 most of the needed food items in the understorey habitat, although net affinities for either habitat 
429 were not significant at two of these sites (Fig. 4). These patterns contrast with northern Norway,

430 where a net affinity for epiphytes was observed. Although abundant epiphytes were found at one

431 site, the understorey habitat at both these sites was generally depauperate and mainly covered by

432 crustose seaweeds, when compared to other regions. If food becomes limited in the understorey,

433 climbing up kelp stipes is probably the best way for a sea urchin to diversify its diet (Bekkby et al.

434 2015). Consumers venturing on the upper part of stipe can actually access Palmaria palmata, which

435 is probably the most palatable red seaweed in the subtidal NE Atlantic kelp forests (Guiry and

436 Blunden 1991; Schaal et al. 2010). Commonly encrusted by the bryozoan Electra pilosa, P.

437 palmata was herein observed in varying abundance as (and only as) epiphytes from France to 438 northern Norway, and this combination of food items made up the entire diet of some individuals

439 from several of the studied localities (JCL, pers. obs.). Further work would be needed to determine 440 the prevalence of possible individual preferences within the sea urchin populations. More 441 interestingly, it is worth noting that Echinus is coexisting with Strongylocentrotus droebachiensis 442 (at densities of ca. 0.5 to $1.2 \mathrm{~m}^{-2}$, Filbee-Dexter et al. 2020) in northern Norway. Should that 443 voracious sea urchin be involved in the control of understorey algae (cf. Christie et al. 2019 and 444 references therein), our feeding behaviour index would thus mirror that competition for food 445 resource affect the foraging flexibility of Echinus, and force it to browse another habitat (Fig. 4B). 446 This point deserves further attention.

448 Potential implications of the scale-dependent foraging strategies of Echinus esculentus for kelp 449 forest functioning along NE Atlantic. 
451 acknowledged, it is noteworthy that not all kelp species share the same habitat-forming traits (e.g.

452 Wernberg et al. 2019 and references therein). Compared to other kelp, the stipe of L. hyperborea

453 possess a series of traits conducive to colonization by abundant perennial and semi-annual 454 epiphytes (reviewed in Teagle and Smale 2018), within which diverse and abundant assemblages 455 of fauna can develop and fuel local and adjacent food webs (Norderhaug et al. 2005; Leclerc et al. 456 2013). Across diverse taxa or morpho-functional groups, sessile epiphytes are indeed characterized 457 by varied structural complexity which have been shown to influence macrofaunal diversity and 458 community structure, at multiple spatial scales (Norderhaug 2004; Norderhaug et al. 2014). A 459 single stipe of kelp can be inhabited by up to 85 macrofaunal species (Leclerc et al. 2016), with 460 abundances that can exceed 80,000 individuals (Christie et al. 2003) and may constitute a 461 microscale diversity refuge in disturbed areas (Leclerc et al. 2015). Although the present data do 462 not provide quantitative evidence for urchin-epiphyte interactions, they align with Bekkby et al. 463 (2015) who demonstrated that Echinus can significantly reduce the abundance of kelp epiphytes in 464 mid-Norway, and thus alter the function of this microhabitat. Interestingly, those authors observed 465 a stronger control of epiphytes in 'young' kelp forests undergoing a process of recolonization post466 overgrazing by Strongylocentrotus droebachiensis, compared to Echinus, which were likely more 467 limited by food availability. The paucity of understorey seaweeds in northern Norway as compared 468 to other regions, regardless of the underlying processes (light limitation, grazing by $S$. 469 droebachiensis), is thus likely to exacerbate Echinus effects upon the diversity and community 470 structure at local scale in these kelp forests. 
473 poorly represented. The most probable explanation for this pattern is that Echinus switches to a

474 kelp-dominated diet only when other food items are limited (even epiphytes were virtually absent

475 locally). This has been seen in previous studies conducted in both UK and Norway: negative effects

476 of Echinus on kelp - and more specifically recruits - are generally observed in "transition" areas,

477 including the lower vertical (i.e. depth) distribution limit of kelp (Jones and Kain 1967), overgrazed

478 areas (Hagen 1983), and localities or patches undergoing a recovery post-harvesting (Steen et al.

479 2016). On the other hand, our results revealed that kelp presented similar contributions to the urchin

480 diet in Portugal as compared to other regions, although their biomass in the urchin habitat was ten-

481 fold lower. Even as a minor component, kelp are rich in carbohydrates and may actually be essential

482 to the mixed diet of the sea urchin. Whether the stronger effect of Echinus on kelp observed in

483 transition areas and lower depth limit can hold for the southern edge of L. hyperborea distribution

484 may be worthy of further investigation (Fig. 4).

In conclusion, we show that the diet and trophic level of an omnivore inhabiting kelp

486 forests, are consistent across four NE Atlantic regions spanning approximately $28^{\circ}$ latitude, despite

487 large differences in habitat structure, temperature, and prey availability. Our results however

488 suggest that generalist consumers can adjust their diet and foraging strategies in response to

489 resource availability at multiple scales. While such plasticity may confer to widely distributed

490 generalist consumers (incl. omnivores) a certain resistance to changing environments and habitats,

491 context dependent feeding behaviour challenges our understanding of associated food webs in 492 response to multiple stressors and biodiversity redistribution. 
494 Acknowledgements. We thank all the people who assisted with diving and logistics at the different

495 localities: L. Lévêque, Y. Fontana, M. Camusat, W. Thomas, N. Guidal and F. Le Ven in Roscoff 496 (Marine operations staff, SBR), N. L. Frisk in Troms $\varnothing$ (Roskilde University, KELPEX). We are

497 grateful to $\mathrm{M}$. Thiel and two anonymous reviewers, whose comments helped substantially to 498 improve the manuscript. JCL further thanks the Centre IDEAL (Investigación Dinámica de

499 Ecosistemas Marinos de Altas Latitudes, Universidad Austral de Chile) for kind hospitality over 500 the manuscript preparation. Funding for this work was provided by the Australian Research 501 Council (TW: FT110100174, TW, KFD: DP190100058), the University of Western Australia 502 Research Collaboration Awards (TW, TdB, JCL, DD, JNF, HC), the France-Australia Science 503 Innovation Collaboration 2014 program (TdB, TW, JCL, DD), Metabomer and Corsaire Core 504 Facility (CL), the French Government run by the National Research Agency with regards to the 505 investment expenditure programme IDEALG ANR-10-BTBR-04 (JCL, DD) and the Norwegian 506 Research Council (TW, MFP, KFD, KELPEX 255085/E40).

508 Data accessibility: Most of the data are provided in the supplementary material associated with 509 the manuscript. Detailed data are available from the corresponding author upon reasonable request. 510 


\section{References}

Anderson MJ, Gorley RN, Clarke KR (2008) PERMANOVA+ for PRIMER: Guide to Software and Statistical Methods. PRIMER-E: Plymouth UK.

Anderson TR, Hessen DO, Boersma M, Urabe J, Mayor DJ (2017) Will invertebrates require increasingly carbon-rich food in a warming world? The American Naturalist 190:725-742

Anstett DN, Naujokaitis-Lewis I, Johnson MT (2014) Latitudinal gradients in herbivory on Oenothera biennis vary according to herbivore guild and specialization. Ecology 95:29152923

Armas C, Ordiales R, Pugnaire FI (2004) Measuring plant interactions: a new comparative index. Ecology 85:2682-2686

Assis J, Tyberghein L, Bosch S, Verbruggen H, Serrão EA, De Clerck O (2018) Bio-ORACLE v2.0: Extending marine data layers for bioclimatic modelling. Global Ecology and Biogeography 27:277-284

Bekkby T, Angeltveit G, Gundersen H, Tveiten L, Norderhaug KM (2015) Red sea urchins (Echinus esculentus) and water flow influence epiphytic macroalgae density. Marine Biology Research 11:375-384

Bell TM, Sotka EE (2012) Local adaptation in adult feeding preference and juvenile performance in the generalist herbivore Idotea balthica. Oecologia 170:383-393

Bennett S, Wernberg T, de Bettignies T, Kendrick GA, Anderson RJ, Bolton JJ, Rodgers KL, Shears NT, Leclerc J-C, Lévêque L, Davoult D, Christie HC (2015a) Canopy interactions and physical stress gradients in subtidal communities. Ecology Letters 18:677-686

Bennett S, Wernberg T, Harvey ES, Santana-Garcon J, Saunders BJ (2015b) Tropical herbivores provide resilience to a climate-mediated phase shift on temperate reefs. Ecology Letters 18:714-723

Blanchet-Aurigny A, Guillou M, Pernet F, Gaffet J-D, Dubois SF (2012) Tissue-diet discrimination factors of isotopic ratios $\left(\Delta \delta^{13} \mathrm{C}\right.$ and $\left.\Delta \delta^{15} \mathrm{~N}\right)$ in two brittle star species: Effect of reproductive state, diet and tissue composition. Journal of Experimental Marine Biology and Ecology 426:68-77

Boersma M, Mathew KA, Niehoff B, Schoo KL, Franco-Santos RM, Meunier CL (2016) Temperature driven changes in the diet preference of omnivorous copepods: no more meat when it's hot? Ecology letters 19:45-53

Bonsdorff E, Vahl O (1982) Food preference of the sea urchins Echinus acutus and E. esculentus. Marine Behaviour and Physiology 8:243-248

Brey T, Müller-Wiegmann C, Zittier ZMC, Hagen W (2010) Body composition in aquatic organisms - A global data bank of relationships between mass, elemental composition and energy content. Journal of Sea Research 64:334-340

Bruno JF, Carr LA, O'Connor MI (2015) Exploring the role of temperature in the ocean through metabolic scaling. Ecology 96:3126-3140

Camps-Castellà J, Romero J, Prado P (2020) Trophic plasticity in the sea urchin Paracentrotus lividus, as a function of resource availability and habitat features. Marine Ecology Progress Series 637:71-85

$556 \quad$ vegetarians? Heat waves and diet shifts in tadpoles. Ecology 97:2964-2974 
Caut S, Angulo E, Courchamp F (2009) Variation in discrimination factors $\left(\Delta^{15} \mathrm{~N}\right.$ and $\left.\Delta^{13} \mathrm{C}\right)$ : the effects of diet isotopic values and applications for diet reconstruction. Journal of Applied Ecology 46:443-453

Chase JM, Biro EG, Ryberg WA, Smith KG (2009) Predators temper the relative importance of stochastic processes in the assembly of prey metacommunities. Ecology Letters 12:12101218

Christie H, Gundersen H, Rinde E, Filbee-Dexter K, Norderhaug KM, Pedersen T, Bekkby T, Gitmark JK, Fagerli CW (2019) Can multitrophic interactions and ocean warming influence large-scale kelp recovery? Ecology and Evolution 9:2847-2862

Christie H, Jørgensen NM, Norderhaug KM, Waage-Nielsen E (2003) Species distribution and habitat exploitation of fauna associated with kelp (Laminaria hyperborea) along the Norwegian coast. Journal of the Marine Biological Association of the United Kingdom 83:687-699

Clay NA, Lehrter RJ, Kaspari M (2017) Towards a geography of omnivory: Omnivores increase carnivory when sodium is limiting. Journal of Animal Ecology 86:1523-1531

Comely CA, Ansell AD (1988) Population density and growth of Echinus esculentus L. on the Scottish west coast. Estuarine, Coastal and Shelf Science 27:311-334

Croll SL, Watts SA (2004) The effect of temperature on feed consumption and nutrient absorption in Procambarus clarkii and Procambarus zonangulus. Journal of the World Aquaculture Society 35:478-488

Dell AI, Pawar S, Savage VM (2014) Temperature dependence of trophic interactions are driven by asymmetry of species responses and foraging strategy. Journal of Animal Ecology 83:70-84

Demko AM, Amsler CD, Hay ME, Long JD, McClintock JB, Paul VJ, Sotka EE (2017) Declines in plant palatability from polar to tropical latitudes depend on herbivore and plant identity. Ecology 98:2312-2321

Dethier MN, Graham ES, Cohen S, Tear LM (1993) Visual versus random-point percent cover estimations:'objective'is not always better. Marine Ecology Progress Series 96:93-100

Emson RH, Moore PG (1998) Diet and gonad size in three populations of Echinus esculentus. In: Mooi R, Telford M (eds) Echinoderms: San Francisco. Balkema, Rotterdam, pp 641-644

Fernandez C, Boudouresque C-F (2000) Nutrition of the sea urchin Paracentrotus lividus (Echinodermata: Echinoidea) fed different artificial food. Marine Ecology Progress Series 204:131-141

Filbee-Dexter K, Pedersen MF, Fredriksen S, Norderhaug KM, Rinde E, Kristiansen T, Albretsen J, Wernberg T (2020) Carbon export is facilitated by sea urchins transforming kelp detritus. Oecologia 192:213-225

Filbee-Dexter K, Wernberg T, Norderhaug KM, Ramirez-Llodra E, Pedersen MF (2018) Movement of pulsed resource subsidies from kelp forests to deep fjords. Oecologia 1987:291-304

Fletcher D, Underwood A (2002) How to cope with negative estimates of components of variance in ecological field studies. Journal of Experimental Marine Biology and Ecology 273:8995

Fredriksen S (2003) Food web studies in a Norwegian kelp forest based on stable isotope $\left(\delta^{13} \mathrm{C}\right.$ and $\delta^{15} \mathrm{~N}$ ) analysis. Marine Ecology Progress Series 260:71-81

Freestone AL, Osman RW, Ruiz GM, Torchin ME (2011) Stronger predation in the tropics shapes species richness patterns in marine communities. Ecology 92:983-993 
603 Gilljam D, Curtsdotter A, Ebenman B (2015) Adaptive rewiring aggravates the effects of species

$604 \quad$ loss in ecosystems. Nature Communications 6:8412

605 Guiry MD, Blunden G (1991) Seaweed resources in Europe: uses and potential, Chichester

606 Hagen NT (1983) Destructuve grazing of kelp beds by sea urchins in Vestfjorden, Northern

607

608

609

610

611

612

613

614

615

616

617

618 Norway. Sarsia 68:177-190

Jones NS, Kain JM (1967) Subtidal algal colonization following the removal of Echinus. Helgoland Marine Research 15:460-466

Kain-Jones JM (1971) Synopsis of biological data on Laminaria hyperborea. FAO Fisheries synopsis 87

Kain JM (1963) Aspects of the Biology of Laminaria hyperborea II. Age, weight and length. Journal of the Marine Biological Association of the United Kingdom 43:129-151

Kelly MS, Owen PV, Pantazis P (2001) The commercial potential of the common sea urchin Echinus esculentus from the west coast of Scotland. Hydrobiologia 465:85-94

Kortsch S, Primicerio R, Aschan M, Lind S, Dolgov AV, Planque B (2019) Food-web structure varies along environmental gradients in a high-latitude marine ecosystem. Ecography 42:295-308

Lares MT, McClintock JB (1991) The effects of food quality and temperature on the nutrition of the carnivorous sea urchin Eucidaris tribuloides (Lamarck). Journal of Experimental Marine Biology and Ecology 149:279-286

Leclerc J-C, Riera P, Laurans M, Leroux C, Lévêque L, Davoult D (2015) Community, trophic structure and functioning in two contrasting Laminaria hyperborea forests. Estuarine, Coastal and Shelf Science 152:11-22

Leclerc J-C, Riera P, Leroux C, Lévêque L, Davoult D (2013) Temporal variation in organic matter supply in kelp forests: linking structure to trophic functioning. Marine Ecology Progress Series 494:87-105

Leclerc J-C, Riera P, Lévêque L, Davoult D (2016) Contrasting temporal variation in habitat complexity and species abundance distributions in four kelp forest strata. Hydrobiologia 777:33-54

Lee KP, Jang T, Ravzanaadii N, Rho MS (2015) Macronutrient balance modulates the temperaturesize rule in an ectotherm. The American Naturalist 186:212-222

Lemoine NP, Drews WA, Burkepile DE, Parker JD (2013) Increased temperature alters feeding behavior of a generalist herbivore. Oikos 122:1669-1678

Minor MA, Scheibling RE (1997) Effects of food ration and feeding regime on growth and reproduction of the sea urchin Strongylocentrotus droebachiensis. Marine Biology 129:159-167

Miyasaka H, Genkai-Kato M (2009) Shift between carnivory and omnivory in stream stonefly predators. Ecological research 24:11-19

Moore HB (1934) A comparison of the biology of Echinus esculentus in different habitats. Journal of the Marine Biological Association of the United Kingdom 19:869-885

Nichols D, Bishop GM, Sime AAT (1985) Reproductive and nutritional periodicities in populations of the European sea-urchin, Echinus Esculentus (Echinodermata: Echinoidea) from the English Channel. Journal of the Marine Biological Association of the United Kingdom 65:203-220

Norderhaug KM (2004) Use of red algae as hosts by kelp-associated amphipods. Marine Biology $144: 225-230$ 
648

649

650

651

652

653

654

655

656

657

658

659

660

661

662

663

664

665

666

667

668

669

670

671

672

673

674

675

676

677

678

679

680

681

682

683

684

685

686

687

688

689

690

691

692

Norderhaug KM, Christie H, Fossa JH, Fredriksen S (2005) Fish-macrofauna interactions in a kelp (Laminaria hyperborea) forest. Journal of the Marine Biological Association of the United Kingdom 85:1279-1286

Norderhaug KM, Christie H, Rinde E, Gundersen H, Bekkby T (2014) Importance of wave and current exposure to fauna communities in Laminaria hyperborea kelp forests. Marine Ecology Progress Series 502:295-301

Paul D, Skrzypek G, Fórizs I (2007) Normalization of measured stable isotopic compositions to isotope reference scales-a review. Rapid Communications in Mass Spectrometry: An International Journal Devoted to the Rapid Dissemination of Up-to-the-Minute Research in Mass Spectrometry 21:3006-3014

Pennings SC, Silliman BR (2005) Linking biogeography and community ecology: latitudinal variation in plant-herbivore interaction strength. Ecology 86:2310-2319

Pinnegar JK, Polunin NVC (1999) Differential fractionation of $\delta^{13} \mathrm{C}$ and $\delta^{15} \mathrm{~N}$ among fish tissues: implications for the study of trophic structure. Functional Ecology 13:225-231

Post D (2002) Using stable isotopes to estimate trophic positions: models, methods, and assumptions. Ecology 83:703-718

Rho MS, Lee KP (2017) Temperature-driven plasticity in nutrient use and preference in an ectotherm. Oecologia 185:401-413

Rosenblatt AE, Schmitz OJ (2016) Climate change, nutrition, and bottom-up and top-down food web processes. Trends in ecology \& evolution 31:965-975

Roslin T, Hardwick B, Novotny V, Petry WK, Andrew NR, Asmus A, Barrio IC, Basset Y, Boesing AL, Bonebrake TC, Cameron EK, Dáttilo W, Donoso DA, Drozd P, Gray CL, Hik DS, Hill SJ, Hopkins T, Huang S, Koane B, Laird-Hopkins B, Laukkanen L, Lewis OT, Milne S, Mwesige I, Nakamura A, Nell CS, Nichols E, Prokurat A, Sam K, Schmidt NM, Slade A, Slade V, Suchanková A, Teder T, van Nouhuys S, Vandvik V, Weissflog A, Zhukovich V, Slade EM (2017) Higher predation risk for insect prey at low latitudes and elevations. Science 356:742-744

Schaal G, Riera P, Leroux C (2010) Trophic ecology in a Northern Brittany (Batz Island, France) kelp (Laminaria digitata) forest, as investigated through stable isotope and chemical assays. Journal of Sea Research 63:24-35

Schmitz OJ, Rosenblatt AE, Smylie M (2016) Temperature dependence of predation stress and the nutritional ecology of a generalist herbivore. Ecology 97:3119-3130

Sentis A, Hemptinne JL, Brodeur J (2014) Towards a mechanistic understanding of temperature and enrichment effects on species interaction strength, omnivory and food-web structure. Ecology letters 17:785-793

Sperfeld E, Wagner ND, Halvorson HM, Malishev M, Raubenheimer D (2017) Bridging ecological stoichiometry and nutritional geometry with homeostasis concepts and integrative models of organism nutrition. Functional Ecology 31:286-296

Steen H, Moy FE, Bodvin T, Husa V (2016) Regrowth after kelp harvesting in Nord-Trøndelag, Norway. ICES Journal of Marine Science: Journal du Conseil 73:2708-2720

Steneck R, Watling L (1982) Feeding capabilities and limitations of herbivorous molluscs: a functional group approach. Marine Biology 68:299-319

Teagle H, Smale DA (2018) Climate-driven substitution of habitat-forming species leads to reduced biodiversity within a temperate marine community. Diversity and Distributions 24:1367-1380 
693

694

695

696

697

698

699

700

701

702

703

704

705

706

707

708

709

710

711

712

713

714

715

716

717

718

719

720

721

722

723

724

725

Tyberghein L, Verbruggen H, Pauly K, Troupin C, Mineur F, De Clerck O (2012) Bio-ORACLE: a global environmental dataset for marine species distribution modelling. Global ecology and biogeography 21:272-281

Tyler P, Young CM, Serafy K (1995) Distribution, diet and reproduction in the genus Echinus: evidence for recent diversification? In: Emson RH, Smith AB, Campbell AC (eds) Echinoderm Research 1995. Balkema, Rotterdam, pp 29-38

Underwood AJ (1997) Experiments in ecology: their logical design and interpretation using analysis of variance. Cambridge University Press, Cambridge, UK

Vanderklift MA, Kendrick GA, Smit AJ (2006) Differences in trophic position among sympatric sea urchin species. Estuarine, Coastal and Shelf Science 66:291-297

Vergés A, McCosker E, Mayer-Pinto M, Coleman MA, Wernberg T, Ainsworth T, Steinberg PD (2019) Tropicalisation of temperate reefs: implications for ecosystem functions and management actions. Functional Ecology 33:1000-1013

Wernberg T, Krumhansl KA, Filbee-Dexter K, Pedersen MF (2019) Status and trends for the world's kelp forests. In: Charles S (ed) World Seas: An Environmental Evaluation, vol Volume III: Ecological Issues and Environmental Impacts, 2nd Edition edn. Elsevier., pp 57-78

Wernberg T, Thomsen MS, Tuya F, Kendrick GA, Staehr PA, Toohey BD (2010) Decreasing resilience of kelp beds along a latitudinal temperature gradient: potential implications for a warmer future. Ecology Letters 13:685-694

Whalen MA, Whippo RDB, Stachowicz JJ, York PH, Aiello E, Alcoverro T, Altieri AH, BenedettiCecchi L, Bertolini C, Bresch M, Bulleri F, Carnell PE, Cimon S, Connolly RM, Cusson M, Diskin MS, D'Souza E, Flores AAV, Fodrie FJ, Galloway AWE, Gaskins LC, Graham OJ, Hanley TC, Henderson CJ, Hereu CM, Hessing-Lewis M, Hovel KA, Hughes BB, Hughes AR, Hultgren KM, Jänes H, Janiak DS, Johnston LN, Jorgensen P, Kelaher BP, Kruschel C, Lanham BS, Lee K-S, Lefcheck JS, Lozano-Álvarez E, Macreadie PI, Monteith ZL, O'Connor NE, Olds AD, O'Leary JK, Patrick CJ, Pino O, Poore AGB, Rasheed MA, Raymond WW, Reiss K, Rhoades OK, Robinson MT, Ross PG, Rossi F, Schlacher TA, Seemann J, Silliman BR, Smee DL, Thiel M, Unsworth RKF, van Tussenbroek BI, Vergés A, Yeager ME, Yednock BK, Ziegler SL, Duffy JE (in press) Climate drives the geography of marine consumption by changing predator communities. Proceedings of the National Academy of Sciences of the United States of America 
728 Table 1. Results of PERMANOVA tests for differences in general response variables among levels

729 of the nested factors (region and site). Degrees of freedom $(d f)$ and components of variation (var,

730 expressed as percentages) are indicated for each factor and response variable. Transformations

731 (Transf) and PERMDISP tests (Disp, for the factor region) are summarized. ${ }^{\mathrm{ns}}$ : non-significant, ${ }^{\mathrm{m}}$ :

732 marginally significant at $\alpha=0.07, *: P<0.05$, **: $P<0.01$, ***: $P<0.001$. Based upon more or

733 less conservative levels (see "Methods" section), significant values are in bold.

\begin{tabular}{|c|c|c|c|c|c|c|}
\hline \multirow{2}{*}{ Response variable } & \multirow[t]{2}{*}{ Transf } & \multirow[t]{2}{*}{ Disp } & \multicolumn{2}{|c|}{ PERMANOVA Factor } & \multirow[b]{2}{*}{$d f \mathrm{Re}, \mathrm{Si}, \mathrm{Res}$} & \multirow[b]{2}{*}{$\begin{array}{c}\text { \%var Re, } \\
\text { Si, Res }\end{array}$} \\
\hline & & & $F$ Region (Re) & $F$ Site $(\mathrm{Si})$ & & \\
\hline \multicolumn{7}{|l|}{ Seaweed biomass (kg m-2) } \\
\hline Laminaria hyperborea & FORT & ns & 74.70** & $0.60 \mathrm{~ns}$ & $3,4,38$ & $79,00,21$ \\
\hline Other kelp & none & $*$ & $16.61 * *$ & $8.50 * * *$ & $3,4,38$ & $83,09,08$ \\
\hline Epiphytes & none & $* * *$ & $1.68 \mathrm{~ns}$ & $2.56^{*}$ & $3,4,38$ & $11,19,70$ \\
\hline Understorey & LOG & ns & $60.75 * *$ & $0.76 \mathrm{~ns}$ & $3,4,38$ & $80,00,20$ \\
\hline \multicolumn{7}{|l|}{ Seaweed cover $(\%)$} \\
\hline Epiphytes & ASIN & ns & $3.75 \mathrm{~ns}$ & $1.33 \mathrm{~ns}$ & $3,4,62$ & $17,03,80$ \\
\hline Understorey & none & $*$ & $32.25 * *$ & $1.41 \mathrm{~ns}$ & $3,4,62$ & $75,01,24$ \\
\hline \multicolumn{7}{|l|}{ Sessile fauna cover $(\%)$} \\
\hline Epiphytes & ASIN & $\mathrm{m}$ & $1.31 \mathrm{~ns}$ & $8.28 * * *$ & $3,4,62$ & $07,42,51$ \\
\hline Understorey & none & ns & $0.46 \mathrm{~ns}$ & $4.69 * *$ & $3,4,62$ & $00,34,76$ \\
\hline \multicolumn{7}{|l|}{$C: N$} \\
\hline Laminaria hyperborea adults & SQRT & $\mathrm{ns}$ & $21.75^{*}$ & $3.32 *$ & $3,4,40$ & $80,05,15$ \\
\hline Laminaria hyperborea young & LOG & $\mathrm{m}$ & $22.39 * *$ & $2.26 \mathrm{~ns}$ & $3,4,40$ & $77,04,19$ \\
\hline E. esculentus & none & $* * *$ & $90.38^{*}$ & $0.48 \mathrm{~ns}$ & $3,4,122$ & $78,00,22$ \\
\hline \multicolumn{7}{|l|}{ d15N } \\
\hline Laminaria hyperborea adults & none & ns & $56.36 * * *$ & $0.79 \mathrm{~ns}$ & $3,4,40$ & $78,00,22$ \\
\hline Laminaria hyperborea young & none & $* * *$ & $1.68 \mathrm{~ns}$ & $18.26 * * *$ & $3,4,40$ & $21,59,20$ \\
\hline E. esculentus & none & $* * *$ & $1.71 \mathrm{~ns}$ & $147.75 * * *$ & $3,4,122$ & $24,68,08$ \\
\hline \multicolumn{7}{|l|}{ Urchin morphometry } \\
\hline Diameter (width) & none & $\mathrm{m}$ & $37.53 * *$ & $2.10 \mathrm{~ns}$ & $3,4,123$ & $69,02,29$ \\
\hline Wet weight & none & $* * *$ & $20.55 * *$ & $5.09 * * *$ & $3,4,123$ & $71,06,23$ \\
\hline Gonad index & ASIN & ns & $0.89 \mathrm{~ns}$ & $9.23 * * *$ & $3,4,123$ & $00,28,72$ \\
\hline Diet composition & SQRT & $* * *$ & $3.947 * *$ & $8.2437 * * *$ & $3,4,120$ & $34,21,45$ \\
\hline Trophic level & none & $* * *$ & $2.40 \mathrm{~ns}$ & $164.02 * * *$ & $3,4,122$ & $39,55,06$ \\
\hline Feeding behaviour Index & none & $* *$ & $9.17 *$ & $11.12 * * *$ & $3,4,120$ & $64,14,22$ \\
\hline
\end{tabular}


SQRT: Square root transformed, FORT: Fourth root transformed, ASIN: Arcsine transformed, LOG: Transformation $\operatorname{Ln}(\mathrm{X}+1)$

735 Figure 1. Mean biomass $\left(\mathrm{kg} \mathrm{m}^{-2}\right)$ of $\operatorname{kelp}(\mathrm{A}, \mathrm{B})$ and other seaweed categories $(\mathrm{C}, \mathrm{D})$ across study

736 sites. Around the median (horizontal line), the box plots show the quartiles, the 95\% confidence

737 intervals (whiskers) and the outliers. Letters, superscript stars $\left(^{*}\right)$ indicate pair-wise differences $(P$

$738<0.05)$ among regions and among sites within regions, respectively. Note that the scale differs

739 among panels.

741 Figure 2. Fleshy seaweed (kelp and crustose algae excluded) and sessile fauna percentage cover

$742(\%)$ estimated upon stipe (epiphytes) and bedrock habitats (understory). The box plots show the

743 total covers (with Q1, Median, Q3, 95\% C.I.s and outliers). The heat maps illustrate the covers of

744 the dominant morpho-functional groups (average SIMPER contribution > 5\%) of fleshy seaweeds,

745 sessile fauna and others. For each category, letters indicate differences among regions, within

746 which superscript stars indicate differences among sites according to PERMANOVA pairwise 747 tests.

749 Figure 3. Trophic level (A), contribution of the main food items (B, average SIMPER contribution

$750>5 \%$ ) to the diet composition (C) of Echinus within and across study sites. Around the median

751 (horizontal line), the box plots show the quartiles, the 95\% confidence intervals (whiskers) and the

752 outlier. Letters and superscript stars indicate pair-wise differences among regions and among sites,

753 respectively. 
755 Figure 4. Feeding behaviour index (A) indicating affinities for epiphytes vs. understorey calculated

756 from the functional similarities between Echinus diet and availability of food items (including

757 seaweeds and fauna) upon kelp stipe and on the bedrock, and illustration of its meaning in the local

758 context (B). Differences between the index values and 0 at the site level are summarized as follow:

$759 *=P<0.05, * *: P<0.01, * * *: P<0.001$.

760 


\subsection{A. Laminaria hyperborea}
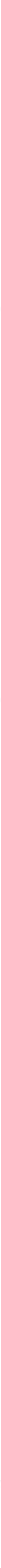
Fleshy seaweed
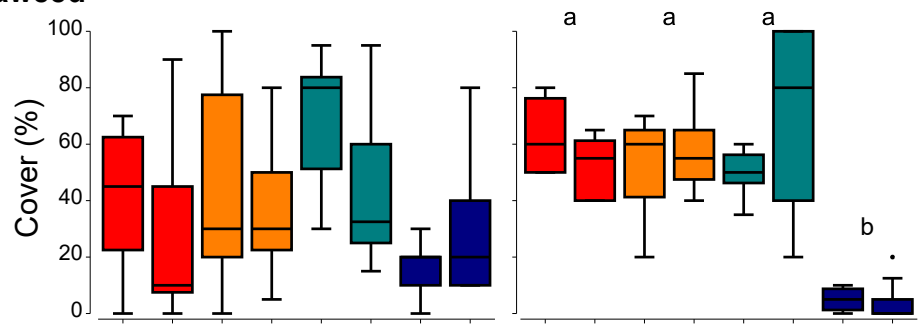

Smooth leaf-like algae Fleshy rough algae Bushy algae

Filamentous algae

Sessile fauna
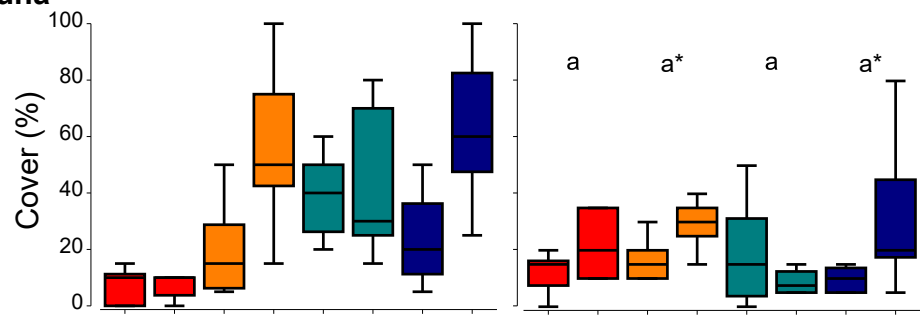

Cirripeda

Crustose Bryozoa Erected Bryozoa

\section{Others}

Sand

Crust. Calc. algae

Crust. Non-Calc. algae C

ESP VDC LAN ROS HAR FIN HEK MAL Por Fra S-Nor $\mathbf{N}-\mathbf{N o r}$

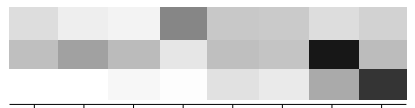

ESP VDC LAN ROS HAR FIN HEK MAL Por Fra S-Nor $\mathbf{N}$-Nor 


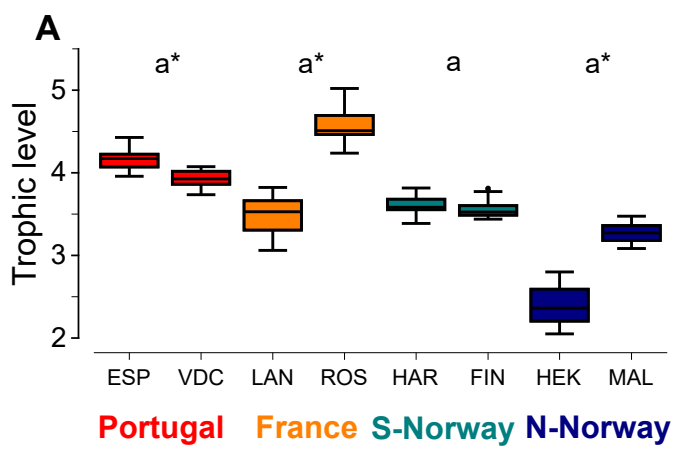

B Main food items

\section{Kelp}

Smooth leaf-like algae

Fleshy rough algae

Bushy algae

Filamentous algae

Crustose Corallinales

Cirripeda

Crustose Bryozoa

Erected Bryozoa

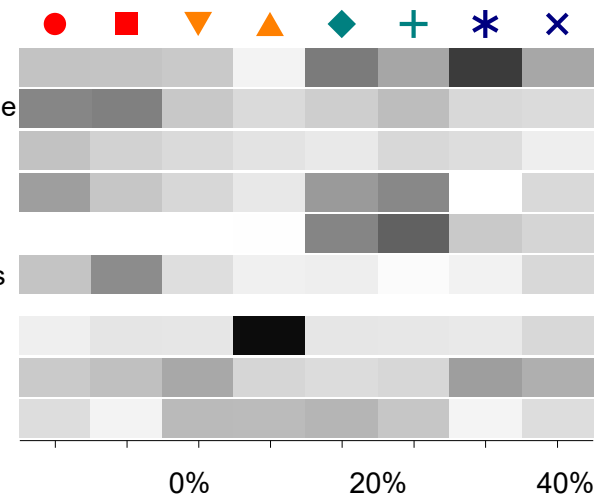

C

Contribution to within-site similarity

$40 \%$

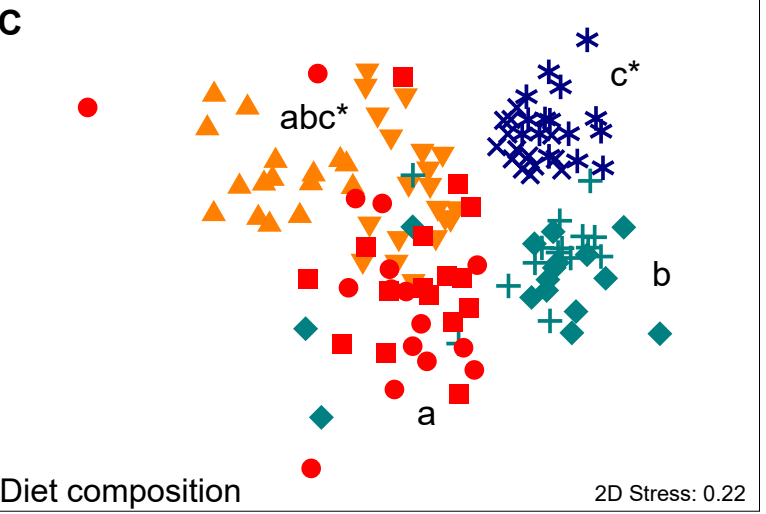


A

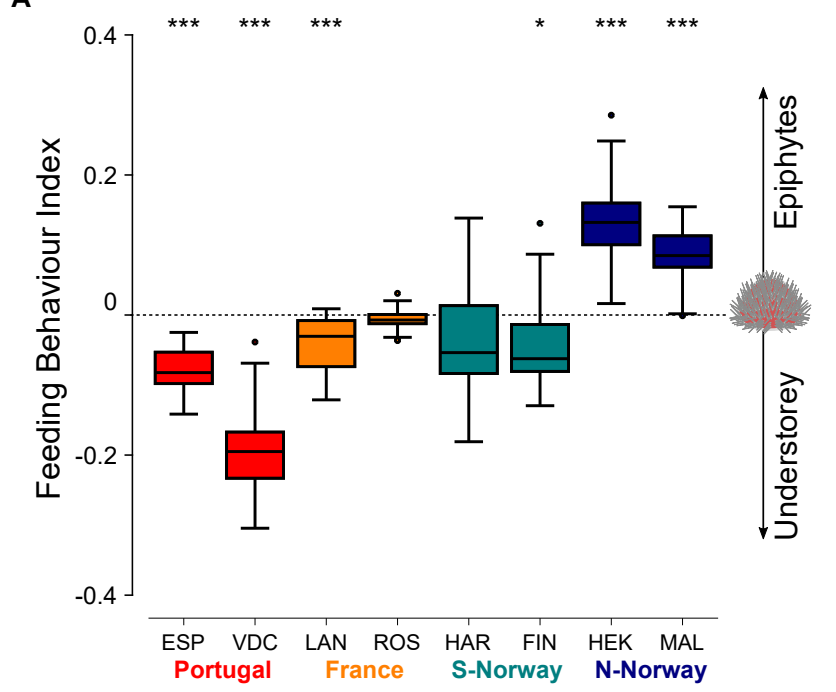

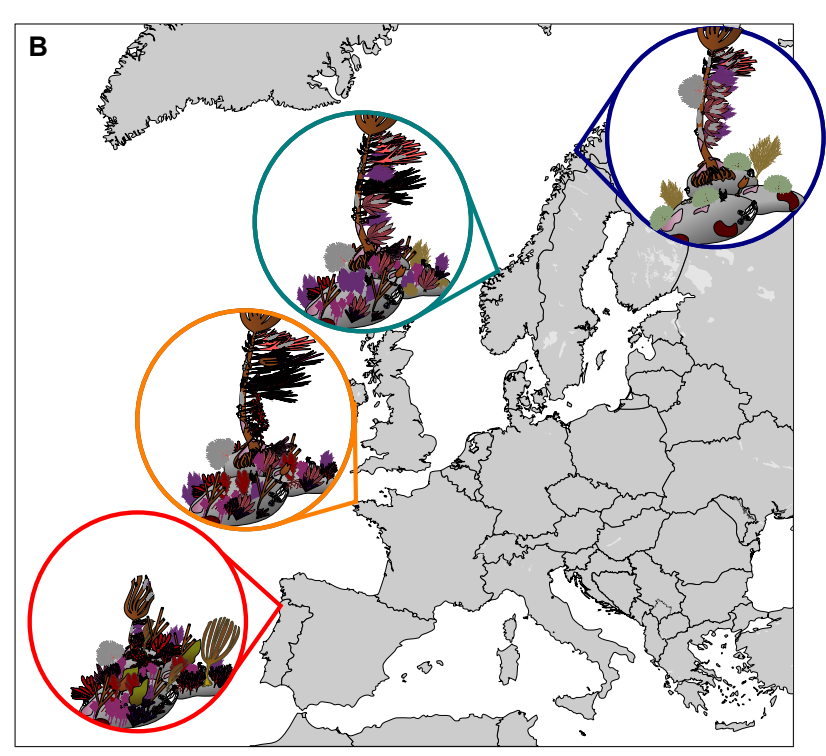

